TITLE:

\title{
A NEW RHYNCHONELLID (BRACHIOPODA) FROM ANTARCTICA
}

AUTHOR(S):

Hatai, Kotora

\section{CITATION:}

Hatai, Kotora. A NEW RHYNCHONELLID (BRACHIOPODA) FROM ANTARCTICA. SPECIAL PUBLICATIONS FROM THE SETO MARINE BIOLOGICAL LABORATORY 1959, 1(4): 1-7

\section{ISSUE DATE:}

1959-05

URL:

http://hdl.handle.net/2433/176434

RIGHT: 
SPECIAL PUBLICATIONS FROM THE SETO MARINE BIOLOGICAL LABORATORY

\author{
BIOLOGICAL RESULTS \\ OF
}

THE JAPANESE ANTARCTIC RESEARCH EXPEDITION

4.

\title{
A NEW RHYNCHONELLID (BRACHIOPODA) FROM ANTARCTICA
}

BY

\section{KOTORA HATAI}

DEPARTMENT OF GEOLOGY

COLLEGE OF EDUCATION,

TOHOKU UNIVERSTTY, SENDAI, JAPAN

SIRAHAMA, WAKAYAMA-KEN

J A.P A N

MAY 1959 
SPECIAL PUBLICATIONS FROM THE SETO MARINE BIOLOGICAL LABORATORY

\author{
BIOLOGICAL RESULTS \\ $\mathrm{OF}$
}

THE JAPANESE ANTARCTIC RESEARCH EXPEDITION

4.

\title{
A NEW RHYNCHONELLID (BRACHIOPODA) FROM ANTARCTICA
}

\section{KOTORA HATAI}

DEPARTMENT OF GEOLOGY, COLLEGE OF EDUCATION, TOHOKU UNIVERSITY, SENDAI, JAPAN

SIRAHAMA, WAKAYAMA-KEN

$J$ A P A N

MA Y 1959 
THIS SERIES contains THE BIOLOGICAL RESULTS OF THE JAPANESE ANTARCTIC RESEARCH EXPEDITION and is published by the Seto Marine Biological Laboratory. Parts will appear at irregular intervals as they become ready. 
THROUGH the kindness of Dr. ToKIoKA of the Seto Marine Biological Laboratory of the Kyoto University at Sirahama, Wakayama Prefecture, an interesting brachiopod obtained by Dr. R. Yosi during the Second Japanese Antarctic Research Expedition was forwarded to the writer for study. An examination of this brachiopod, which consisted of only a single specimen, showed that it is an undescribed species, whose description is given in this article.

\section{Phylum BRACHIOPODA}

Superfamily Rhynchonellacea ScHUCHERT, 1896

Family Rhynchonellidae GrAY, 1848

Genus Hispanirhynchia Thomson, 1927

Genotype:-Rhynchonella cornea DAvIDSON, 1887.

Type locality :-Off Cape St. Vincent, in 57.5 fathoms, Talisman Expedition (fide W. H. DALL, 1920).

\section{Hispanirhynchia antarctica H.ATAI, n, sp.}

(Figs. 1-4)

Description:--Shell of moderate size for the genus, measuring about $12.0 \mathrm{~mm}$ in length, $11.0 \mathrm{~mm}$ in width and nearly $6.0 \mathrm{~mm}$ in depth of intact valves. Shell roundly trigonal in outline, nearly equiconvex, maximum convexity near or a little posterior to middle of shell length. Test thin, light grayish brown in color, structure impunctate. Lateral commissure straight, anterior rectimarginate, no development of mesial sinus or ligation anteriorly. Beak small, pointed, rhynchonelliform, slightly curved over dorsal umbo, provided with incomplete oval-shaped, posteriorly notched foramen which penetrates extremity of rhynchonelliform beak. Cardinal margin broadly rounded. Deltidial plates triangular in shape, sharply defined from postero-dorsal parts of shell by deep groove, disjunct, sculptured with transverse rough striations, below converging but not uniting below foramen. Pedicle-collar short, stuated at posterior one-third of and within foramen, continuous with posterior part of foramen, not adhered to shell-wall. Surface of both valves provided with numerous longitudinal riblets, which are much broader than their narrow valley-like 
interspaces, numbering about eight to nine per millimeter at anterior margin, their number increasing from posterior to anterior part of valves by bifurcation of the main ribs and by addition of secondary ones by interpolation at different situations. Ribs broadly rounded, rather flat on top, crossed with periodic strong and numerous very weak concentric growth lines to give a more or less cancellated aspect under magnification. No development of spinuous structures at point of junction of radial and transverse sculptures. Interior of ventral valve with hinge-teeth more or less roughened at their dorsally directed extremities, separated from shell-wall by narrow grooves, below or ventrally supported by ventrally and posteriorly recessive dental plates which are rather

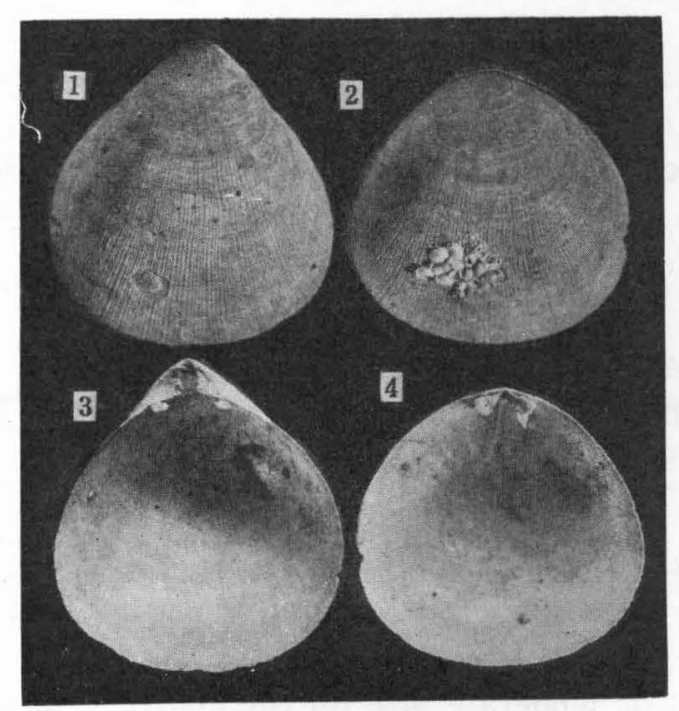

Figs. 1-4. Hispanirhynchia antarctica HATAI, n. sp. 1-ventral view, 2-dorsal view, 3 -interior of ventral valve, 4-interior of dorsal valve. $\times 3$

thin and short, leaving between them and shell-wall a narrow shallow cavity. Ventral muscular impressions at posterior central part, large, more or less of irregular heart-shape. Interior of dorsal valve with small, narrowly diverging ribbon-like crura separated from shell-wall by deep, oblique sockets. Crura oblique, roughened at upper or ventral extremities, inner border strong, more or less ridge-like and stronger than outer ones, which are narrow and bladelike, area between both ridges slightly concave and narrowly trough-like, forming external hinge-plates. No internal hinge-plates nor cardinal process. Median septum or septal ridge not continuous with crural bases posteriorly but terminating below, short, narrow, blade-like, low, its bases broadened, confined 


\section{A New Rhynchonellid (Brachiopoda) from Antarctica}

to posterior extremity of dorsal valve. Median ridge with two smaller ones, one on each side, much lower and weaker, more or less thread-like in appearance, as extensive anteriorly as median one, all parallel with one another, separated from one another by narrow, round-bottomed troughs. Dorsal muscular impressions faint, situated on outer sides of mesial ridges, elongate, oval in shape. Soft parts not preserved.

Remarks :-Owing to that only a single specimen of this interesting brachiopod is in the present collection, nothing can be ascertained concerning its size range, degree of variation in the surface sculpture and outline, variation in the convexity of the valves and color, or whether folding at the anterior margin as seen in many rhynchonellids will develop with the advance of age. Since there is only a single specimen at disposal the test was not sectioned for microscopic examination of its structure. Because the animal is not preserved, nothing is known concerning it. However, the specimen exhibits several charactersitic features which seem to be of specific value, such as the, (1) rectimarginate folding in a shell length of about $12.0 \mathrm{~mm}$, which size suggests that the animal is in the mature stage and that folding will not develope, (2) the long oval-shaped incomplete, slightly notched foramen penetrating the rhynchonelliform beak, (3) development of three mesial parallel ridges in the posterior part of the dorsal valve, among which the middle one is largest, (4) eight to nine radial ribs per one millimeter at the anterior margin of the valves, (5) increasing anteriorly of the radial riblets by both bifurcation of the major ones and by interpolation of minor ones, (6) development of troughlike external hinge-plates, bordered on both inner and outer sides with ridges, and, (7) characteristic weak cancellated surface sculpture of the valves formed by the intersection of radial riblets and concentric growth lines.

Rhynchonella cornea P. FISHER (MS) DAviDSON (1886, p. 171, pl. 25, figs. 2-4), which is the genotype of Hispanirhynchia THOMSON (1927, p. 159, fig. 49), also well figured by FISCHER and OEHLERT (1891, p. 13, pl. 1, figs. 2 a-2 u) under the name of Rhynchonella (Hemithyris) cornea P. FISCHER, more or less resembles the present specimen. However, the ligate anterior margin of Hispanirhynchia cornea is a feature not observed in the present material, and the presence of three longitudinal mesial ridges on the floor of the dorsal valve of $H$. antarctica is a character not reported in DAvidson's species. Further, the outline of the shell of the genotype is trigonal with the maximum width anteriorly, while in the present new species, the shell is more circular, and the number of radial riblets in $H$. comea (about 60 per centimeter) is less than in the present one. From such reasons, although evidently closely allied, the present specimen is distinguished from the genotype of Hispanirhynchia.

The type of cardinalia, development of three mesial ridges in the dorsal valve, rectimarginate folding with no tendency to ligation, characters of the 
beak and foramen, type of external sculpture, notched foramen, and details of the hinge-teeth and dental plates seem to serve for distinguishing antarctica from such Rhynchonellids as Tegulorhynchia CHAPMAN and CRESPIN (1923), Compsothyris JACKSON (1918), and Hemithyris D'ORBIGNY (1847). Compsothyris has inner hinge-plates and the posterior part of the mesial septum is fused with them; such feature does not occur in the present specimen.

Although distinction of the present specimen from the mentioned genera may be done as stated, there still remains some doubt as to the true position of the newly proposed species, particularly in that the weakly notched foramen. seen in antarctica is a characteristic of the genus Compsothyris and is not reported in the generic diagnosis of Hispanirhynchia.

The genus Hispanirhynchia, according to THOMSON (1927, pp. 159-151), contains such species as, (?) Hemithyris eotrigona SACCO from the Eocene of Italy, (?) Hemithyris eotrigona obliquatella SACCO from the Eocene of Italy, Rhynchonella sicula (SEguenza MS) DAvidSON from the Pliocene of Italy, Rhynchonella cornea DAvidSON from the East Atlantic from the English Channel to the Canary Islands in 240-1,102 fathoms, (?) Hemithyris craneana DALL from off Cocos Island in the Gulf of Panama in 1,175 fathoms, and (?) Hemithyris bartschi DALL from the Molucca Pass and Philippines in 161-298 fathoms. The new species described in this article is the seventh one.

Type locality:-In Lützow Holm Bay from a depth of 570 meters, Antarctica. Recent. Coll. Japanese Antarctic Expedition, February 8, 1958.

\section{REFERENCES}

BlochmanN, F. 1906. Neue Brachiopoden der Valdivia -und Gaussexpedition. Zool. Anz., Bd. 30, Heft 21/22, pp. 690-702, 3 figs.

1912. Die Brachiopoden der Schwedischen Südpolar-Expedition. Wissen. Ergeb.

Schwedischen Siidpolar-Exped., 1901-1903, 12 pp., 3 pls.

BuCKMAN, S. S. 1910. Antarctic Fossil Brachiopoda Collected by the Swedish South Polar Expedition. Wissen. Ergeb. Siidpolar-Exped., 1901-1903, 43 pp., 3 pls., 1 fig.

Chapman, F., and I. CREspin 1923. The Austral Rhynchonellacea of the "Nigricans Series", with a Special Description of the New Genus Tegulorhynchia. Proc. Roy. Soc. Victoria, Vol. 35 (N. S.) pp. 170-193, pls. 11-13.

COOPER, G. A. 1957. Tertiary and Pleistocene Brachiopods of Okinawa, Ryukyu Islands. U. S. Geol. Surv. Prof. Paper $314-A, 20$ pp., 5 pls.

DALL, W. H. 1920. Annotated List of Recent Brachiopoda in the Collection of the United States National Museum, with the Descriptions of Thirty-three New Forms. Proc. U. S. Nat. Mus., Vol. 57, No. 2314 , pp. $261-377$.

Davinson, T. 1887-88. A Monograph of Recent Brachiopoda. Trans. Linn. Soc. London, Ser. 2, Vol. 4, Pt. 2, pp. 75-182, pls. 14-25, 1887 ; Vol. 4, Pt. 3, pp. 183-248, pls. 26-30, 1888.

1880. Sci. Rep., Voyage H. M. S. Challenger, 1873-76, Zool., Vol. 1, Pt. 1, Rep.

Brachiopoda, 67 pp., 4 pls.

Frscher, P., and P. D. Oehlert 1891. Expéd. Sci., Travailler et du Talisman, 1880, 1881, 1882, 1883, Brachiopodes, 139 pp., 8 pls., 14 figs. 


\section{A New Rhynchonellid (Brachiopoda) from Antarctica}

HATAI, K. 1940. Cenozoic Brachiopoda of Japan. Sci. Rep., Tohoku Imp. Univ., Ser. 2, Vol. 20, 413 pp., 12 pls.

Helmcke, J. G. 1940. Die Brachiopoden der Deutschen Tiefsee-Expedition. Wissen. Ergeb. Deutschen Tiefsee-Exped., "Valdivia" 1898-1899, pp. 217-316, 43 figs.

Hertlein, L. G. and U. S. Grant IV 1944. The Cenozoic Brachiopoda of Western North America. Univ. Calif., Los Angeles, Vol. 3, 236 pp., 21 pls., 34 figs.

JACKson, J. W. 1918. Brachiopoda. British Antarctic ("Terra Nova") Expedition, 1910. Brit. Mus., Nat., Hist., Zool., Vol. 2, pp. 177-202, 1 pl.

Joubin, L. 1901. Brachiopodes. Expéd. Antarctique Belge. Res. Voyage du S. Y. Belgica, 1897-18981899, pp. 3-11, 2 pls., 1 fig.

Simrorh, H. 1897. Die Brachiopoden der Plankton-Expedition. Ergeb. Plankton-Exped., HumboldtStiftung, pp. $3-17,1$ pl.

Thomson, J. A. 1927. Brachiopod Morphology and Genera (Recent and Tertiary). New Zealand Bd. Sci. Art., Man. No. 7, 338 pp., 2 pls., 103 figs. 


\section{BIOLOGICAL RESULTS \\ OF \\ THE JAPANESE ANTARCTIC RESEARCH EXPEDITION}

1. Tanita, Senji: Sponges. 1959.

$¥ 50$

2. NAKASEKo, Kojiro: On Superfamily Liosphaericae (Radiolaria) from sediments in the sea near Antarctica (On Radiolaria from sediments in the sea near Antarctica. Part 1). 1959.

$¥ 150$

3. Hirano, Minoru: Notes on some algae from the Antarctic collected by the Japanese Antarctic Research Expedition. 1959.

150

4. HataI, Kotora: A new rhynchonellid (Brachiopoda) from Antarctica. 1959. 50

5. TоктокA, Takasi : Amaroucium erythraeum Michaelsen, a compound ascidian from the Cape Province. 1959.

¥0 